\title{
The effects of the COVID-19 pandemic on levels of physical fitness
}

\author{
(iD) Cristiano Silva Pinho $0^{\mathbf{1 4}}$ \\ (D) Alex Cleber Improta Caria ${ }^{2,3}$ \\ (iD Roque Aras Júnior ${ }^{2}$ \\ (iD) Francisco José Gondim Pitanga $a^{3,4}$
}

\begin{abstract}
1. Programa de Pós-Graduação em Engenharia, União de Faculdades de Alagoas, Unifal - FIC, Maceió, AL, Brasil. 2. Programa de Pós-Graduação em Medicina e Saúde, Faculdade de Medicina e Saúde, Universidade Federal da Bahia (UFBA), Salvador, BA, Brasil. 3. Departamento de Educação Física em Cardiologia da Sociedade Brasileira de Cardiologia (Defic-SBC), seção Bahia, Salvador, BA, Brasil.

4. Instituto de Saúde Coletiva, Universidade Federal da Bahia (UFBA), Salvador, BA, Brasil.
\end{abstract}

SUMMARY

INTRODUCTION: The COVID-19 pandemic, caused by infections from a novel human coronavirus, has been reported since December 2019 in China but was only made official in March 2020. Since then, it has had an impact worldwide, both due to its aggressiveness and its fast propagation. Society has been facing this pandemic by following the recommendations and determinations of the WHO and the strategies deployed by governmental institutions. Among these, social isolation has been shown to be the most important, because when isolating, society tends to move less, with a consequent increase in physical inactivity and sedentary behavior, affecting its levels of physical fitness. The objectives of this review were: to review the most important effects of physical inactivity and sedentary behavior on the physical fitness levels of the population during the COVID-19 pandemic.

CONCLUSION: The role of a regular practice of activities on the levels of physical fitness is fundamental to define the balance of quality of life during a COVID-19.

KEYWORDS: Physical Fitness. Coronavirus Infections. Sedentary Behavior. Betacoronavirus.

\section{INTRODUCTION}

The pandemic caused by infections from a new virus, known as new human coronavirus (COVID19), was notified in December 2019, in China, but only formalized in March 2020 and, since then, has impacted nations throughout the world, both due to its aggressiveness and its speed of propagation'. The figures are alarming: on 3 June 2020, the World Health Organization confirmed 6,317,450 cases and 376,320 deaths worldwide ${ }^{2}$.
Society, still without a vaccine, has been handling the COVID-19 pandemic through various strategies, trying to strictly follow the recommendations by the World Health Organization (WHO) and the determinations of governmental measures, through extendable decrees focusing on: proportional emergency care, cleaning, disinfection, compulsory use of masks, social distancing, social isolation and, in certain cases, quarantine, and lockdown ${ }^{2}$. 
Among these measures, social isolation determines that population should mainly at home, ceasing, thus, their working life, as well the regular practice of physical activity in their daily routine, leading to an increase in physical inactivity and sedentary behavior and its consequences.

Physical inactivity is characterized by a condition under which the recommended levels of physical activity of moderate and vigorous intensity (MVPA) 3 are not reached, while sedentary behavior is characterized by the practice of activities with low energy expenditure: $\leq 1.5$ metabolic equivalents (METs) (Figure 1), for example, remaining in a sitting, leaning, or lying position over 8 hours per day, except for the period of sleep ${ }^{4-6}$. Both are harmful to health and reduce the levels of physical fitness.

The importance of maintaining in of physical fitness, through the practice of regular physical activity, needs to be better understood in its dimensions so that it can be properly recognized as an activity that is essential for health, in a consensus between society, science, and the government bodies since it is an excellent strategy for its positive effects on cardiovascular, metabolic, immunological, and mental health ${ }^{7.8}$. Therefore, the objectives of this review were: to review the most important effects of physical inactivity and sedentary behavior on the levels of physical fitness of the population during the COVID-19 pandemic.

\section{Levels of physical fitness}

The levels of physical fitness have been analyzed by the American College of Sports Medicine, and in cases

FIGURE 1. DIFFERENCE BETWEEN SEDENTARY, PHYSICALLY INACTIVE, AND PHYSICALLY ACTIVE BEHAVIOR. ADAPTED FROM MENEGUCI ET AL. ${ }^{4}$

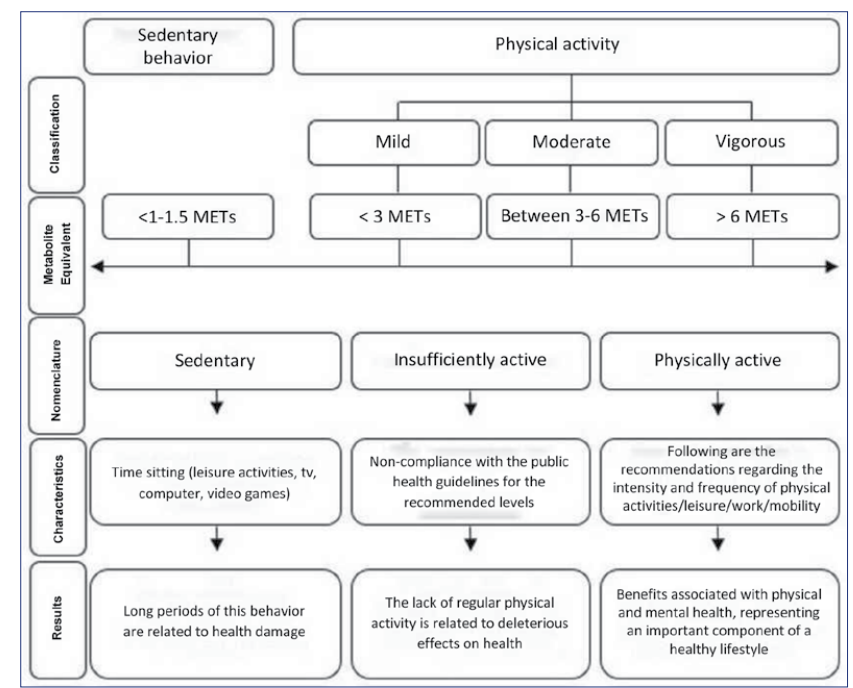

of its reduction or decline, the effects of aging accelerators would be revealed ${ }^{9}$. Based on these studies, Table 1 gives an idea of what these adaptations would look like in conditions of physical inactivity during the COVID-19 pandemic:

The increase in physical inactivity and sedentary behavior during the COVID-19 pandemic can be explained by two important reasons. The first relates to the fact that there were already existing cases of physical inactivity pre-pandemic, and the second is the transitory cases caused by the imposition of a essentially confined life, both converging in the decline of physical fitness ${ }^{7}$.

These two reasons together may increase cases of complications and even deaths, both from reasons other than COVID-19. This may even lead to cardiovascular and respiratory complications, considering that physical inactivity is considered a risk factor for cardiovascular and metabolic diseases ${ }^{10}$ due to its correlation with increased blood pressure, blood glucose, and lipid profile" ${ }^{11}$. The increase in physical inactivity associated with longer periods of sedentary behavior

TABLE 1. RELATIONSHIP OF ELEMENTS OF PHYSICAL FITNESS, ORGANIC EFFECTS, AND FUNCTIONAL IMPACTS OF PHYSICAL INACTIVITY.

\begin{tabular}{|c|c|c|}
\hline $\begin{array}{l}\text { Physical } \\
\text { Fitness }\end{array}$ & Effect observed & Functional impact \\
\hline $\begin{array}{l}\text { Strength and } \\
\text { Power of } \\
\text { muscles }\end{array}$ & $\begin{array}{l}\text { The levels of isometric and } \\
\text { concentric strength decrease } \\
\text { quickly during periods of } \\
\text { physical inactivity. Power } \\
\text { declines faster than Strength. }\end{array}$ & $\begin{array}{l}\text { Deficits of strength } \\
\text { and power are pre- } \\
\text { dictors of disability } \\
\text { and increased risk } \\
\text { of mortality }\end{array}$ \\
\hline $\begin{array}{l}\text { Endurance, } \\
\text { Fatigability } \\
\text { and Cardio- } \\
\text { respiratory } \\
\text { function }\end{array}$ & $\begin{array}{l}\text { Endurance decreases. } \\
\text { The maintenance of strength } \\
\text { becomes difficult. } \\
\text { The maximum aerobic power } \\
\text { (MAP) decreases. }\end{array}$ & $\begin{array}{l}\text { It can affect the } \\
\text { recovery from } \\
\text { repetitive daily } \\
\text { activities; } \\
\text { Cardiorespiratory } \\
\text { system overload }\end{array}$ \\
\hline $\begin{array}{l}\text { Balance and } \\
\text { Mobility }\end{array}$ & $\begin{array}{l}\text { Changes in the sensory, } \\
\text { motor, and cognitive patterns } \\
\text { that would affect the bio- } \\
\text { mechanics (sitting, standing, } \\
\text { moving, etc.). These ele- } \\
\text { ments, added to the matter } \\
\text { of environment limitations, } \\
\text { would affect balance and } \\
\text { mobility }\end{array}$ & $\begin{array}{l}\text { Loss of balance } \\
\text { causes fear of } \\
\text { falling and may } \\
\text { lead to a rejection } \\
\text { of the practice of } \\
\text { physical activity. }\end{array}$ \\
\hline $\begin{array}{l}\text { Performance } \\
\text { and Motor } \\
\text { control }\end{array}$ & $\begin{array}{l}\text { Increases the reaction time } \\
\text { (may lead to accidents). } \\
\text { The speed of simple and } \\
\text { repetitive movements may } \\
\text { decrease } \\
\text { Change in the control of } \\
\text { gesture precision. Difficulty in } \\
\text { performing complex tasks. }\end{array}$ & $\begin{array}{l}\text { Impact on instru- } \\
\text { mental activities of } \\
\text { daily living (IADL). } \\
\text { Increases the like- } \\
\text { lihood of accidents } \\
\text { and injuries. }\end{array}$ \\
\hline $\begin{array}{l}\text { Flexibility and } \\
\text { Amplitude of } \\
\text { Joint Move- } \\
\text { ment }\end{array}$ & $\begin{array}{l}\text { There is a marked decrease } \\
\text { in the flexing degree of joints } \\
\text { such as the hips, spine, and } \\
\text { ankle }\end{array}$ & $\begin{array}{l}\text { Little flexibility, } \\
\text { increase risk of } \\
\text { injury, decreased } \\
\text { mobility, backache, } \\
\text { and falls. }\end{array}$ \\
\hline
\end{tabular}


can also induce cardiovascular morbidity and mortality due to all the causes ${ }^{12}$. However, individuals who are physically active have significantly reduced mortality due to cardiovascular diseases, even with long periods of sedentary behavior ${ }^{13}$, because they improve their cardiorespiratory fitness and prevent various chronic diseases ${ }^{14}$.

Thus, being physically active and reducing sedentary behavior during the COVID-19 pandemic are essential to maintain levels of physical fitness, aiding in the balance and improvement of several physical valences, promoting a better quality of life and general health ${ }^{15}$, in addition to reducing the risk of cardiovascular and metabolic diseases, at any time, including during the COVID-19 pandemic ${ }^{16}$.

It is important to highlight that the elderly population is at a greater risk of complications and death during the COVID-19 pandemic, no matter how well preserved it is in social isolation, because the increase in physical inactivity and sedentary behavior, which reduces their levels of physical fitness, can make them more prone to cardiovascular events, and they may suffer from an accelerated organic and cognitive decline, including the possibility of falls due to postural imbalance.

In this context, in times of difficulty, with the goal of trying to maintain a normal behavior of physical activity practice to improve physical valences and physical fitness, the technologies normally associated to hypokinesia, currently, would have a beneficial and strategic role of virtually bringing together Physical Education professionals and their clients. Both groups are trying to adapt to this model of distant instruction, through applications, for the remote practice of physical activities and exercises, gathering in virtual social networks, through lives, pre-recorded lectures, audio classes, and various media elements ${ }^{17}$.

However, the screen time, an important variable in the study of sedentary behavior ${ }^{18}$, presents itself, at this moment, as a factor for future studies because individuals who spend too much time using devices such as laptops, phones, or TVs increase a component of sedentary behavior which is harmful to health and is associated with a risk of developing obesity $^{19}$; on the other hand, technology can also be a tool to promote health and improve physical fitness, because games combined with movement and motivational elements, as already seen in the concept of exergaming ${ }^{20.21}$ applied to technological exercise equipment, promote competitive games, racing simulations, among others, in the form of videogames or digital neurocognitive games known as brain games $^{22}$. Although both are composed of simultaneous elements of motivation and data monitoring, the latter would have more characteristics to reduce sedentary behavior.

Therefore, several strategies can be adopted to inhibit physical inactivity and reduce sedentary behavior during the COVID-19 pandemic, thus minimizing the risk of chronic-degenerative diseases, as well as of morbidity and mortality.

\section{CONCLUSION}

Practicing physical activities has a key role in the levels of physical fitness and is essential to balance and improve health and quality of life during the COVID19 pandemic because it reduces the levels of physical inactivity and sedentary behavior.

Thus, the practice of regular physical activity is essential because it minimizes harmful effects on physical and emotional health during the pandemic, particularly by maintaining and/or improving the clinical condition of individuals who have chronic diseases.

\section{Author's Contribution}

All authors contributed equally to this study.

\section{RESUMO}

INTRODUÇão: A pandemia de COVID-19, causada pela infecção por novo coronavírus humano, foi notificada desde dezembro de 2019 , na China, mas apenas oficializada em março de 2020 e, desde então, tem impactado nações do mundo inteiro, tanto pela sua agressividade quanto pela sua velocidade de propagação. A sociedade enfrenta a pandemia seguindo as recomendações e determinações da OMS e das instituições governamentais. Entre as estratégias de enfrentamento, o isolamento social se destaca como o mais importante, porque, ao se isolar, a sociedade tende a se mover menos, obtendo aumento da inatividade física e do comportamento sedentário, reduzindo seus níveis de aptidão física. Os objetivos dessa revisão foram: revisar os efeitos mais importantes da inatividade física e do comportamento sedentário sobre os níveis de aptidão física da população durante a pandemia de COVID-19.

CONCLUSÃO: O papel da prática regular de atividades físicas sobre os níveis de aptidão física se revela fundamental para estabelecer o equilíbrio na qualidade de vida durante a COVID-19. 


\section{REFERENCES}

1. Holshue ML, DeBolt C, Lindquist S, Lofy KH, Wiesman J, Bruce H, et al; Washington State 2019-nCoV Case Investigation Team. First case of 2019 novel coronavirus in the United States. N Engl J Med. 2020;382(10):929-36.

2. World Health Organization. Coronavirus disease (COVID-2019) situation reports. 2020. [cited 2020 May 28]. Available from: https://www.who.int/ emergencies/diseases/novel-coronavirus-2019/situation-reports

3. Hallal PC, Bauman AE, Heath GW, Kohl $3^{\text {rd }}$ HW, Lee IM, Pratt M. Physical activity: more of the same is not enough. Lancet. 2012;380(9838):190-1.

4. Meneguci J, Santos DAT, Silva RB, Santos RG, Sasaki JE, Tribess S, et al. Comportamento sedentário: conceito, implicações fisiológicas e os procedimentos de avaliação. Motricidade. 2015;11(1):160-74.

5. Owen N, Healy GN, Matthews CE, Dunstan DW. Too much sitting: the population health science of sedentary behavior. Exerc Sport Sci Rev. 2010;38(3):105-13.

6. Pate RR, O'Neill JR, Lobelo F. The evolving definition of "sedentary". Exerc Sport Sci Rev. 2008;36(4):173-8.

7. Pitanga FJG, Beck CC, Pitanga CPS. Atividade física e redução do comportamento sedentário durante a pandemia do coronavírus. Arq Bras Cardiol. 2020. DOI: https://doi.org/10.36660/abc.2020023

8. Pitanga FJG, Beck CC, Pitanga CPS. Should physical activity be considered essential during the COVID-19 pandemic? Int J Cardiovasc Sci. 2020. DOI: https://doi.org/10.36660/ijcs.20200072.

9. Matsudo SMM. Envelhecimento, exercício e saúde: guia prático de prescrição e orientação. $3^{a}$ ed. São Paulo: Midiograf; 2013.

10. Carnethon MR. Physical activity and cardiovascular disease: how much is enough? Am J Lifestyle Med. 2009;3(1 Suppl):44S-9.

11. Rissardi GGL, Cipullo JP, Moreira GC, Ciorlia LAS, Cesarino CB, Giollo Junior $L T$, et al. Prevalence of physical inactivity and its effects on blood pressure and metabolic parameters in a brazilian urban population. Int I Cardiovasc Sci. 2018;31(6):594-602.
12. Young DR, Hivert MF, Alhassan S, Camhi SM, Ferguson JF, Katzmarzyk PT; et al. Sedentary behavior and cardiovascular morbidity and mortality: a science advisory from the American Heart Association. Circulation. 2016;134(13):e262-e79.

13. Warren TY, Barry V, Hooker SP, Sui X, Church TS, Blair SN. Sedentary behaviors increase risk of cardiovascular disease mortality in men. Med Sci Sports Exerc. 2010;42(5):879-85.

14. Lavie Cl, Ozemek C, Carbone S, Katzmarzyk PT, Blair SN. Sedentary behavior, exercise, and cardiovascular health. Circ Res. 2019;124(5):799-815.

15. Chen P, Mao L, Nassis GP, Harmer P, Ainsworth BE, Li F. Coronavirus disease (COVID-19): the need to maintain regular physical activity while taking precautions. J Sport Health Sci. 2020;9(2):103-4.

16. Zhu W. Should, and how can, exercise be done during a coronavirus outbreak? An interview with Dr. Jeffrey A. Woods. J Sport Health Sci. 2020;9(2):105-7.

17. Raiol RA. Praticar exercícios físicos é fundamental para a saúde física e mental durante a Pandemia da COVID-19. Braz J Hea Rev. 2020;3(2):2804-13.

18. Robinson TN, Banda JA, Hale L, Lu AS, Fleming-Milici F, Calvert SL, et al. Screen media exposure and obesity in children and adolescents. Pediatrics. 2017;140(Suppl 2):S97-S101.

19. Biddle SJH, García Bengoechea E, Pedisic Z, Bennie J, Vergeer I, Wiesner G. Screen time, other sedentary behaviours, and obesity risk in adults: a review of reviews. Curr Obesity Rep. 2017;6(2):134-47.

20. Oliveira B, Nesteriuk S, Queiroz P. Exergames: amostragem da produção acadêmica entre 2010 e 2015. Proceedings of XV Simpósio Brasileiro de Jogos e Entretenimento Digital; 2016. p.714-7.

21. Viana RB, Vancini RL, Andrade MS, Vieira CA, Lira CAB. O uso dos exergames nos protocolos de reabilitação em diversas populações clínicas. Rev Bras Pesq Saúde. 2018;20(3):132-40.

22. Cardoso NO, Landenberger T, Argimon IIL. Jogos eletrônicos como instrumentos de intervenção no declínio cognitivo: uma revisão sistemática. Rev Psicol IMED. 2017;9(1):119-39. 